\title{
The GLP-1 Analogue Exenatide Improves Hepatic and Muscle Insulin Sensitivity in Diabetic Rats: Tracer Studies in the Basal State and during Hyperinsulinemic-Euglycemic Clamp
}

\author{
Hui Wu, Chunhua Sui, Hui Xu, Fangzhen Xia, Hualing Zhai, Huixin Zhang, Pan Weng, \\ Bing Han, Sichun Du, and Yingli Lu
}

Institute and Department of Endocrinology and Metabolism, Shanghai Ninth People's Hospital Affiliated Shanghai Jiaotong University School of Medicine, Shanghai 200011, China

Correspondence should be addressed to Yingli Lu; luyingli2008@126.com

Received 14 August 2014; Revised 17 October 2014; Accepted 18 October 2014; Published 16 November 2014

Academic Editor: Bernard Portha

Copyright (C) 2014 Hui Wu et al. This is an open access article distributed under the Creative Commons Attribution License, which permits unrestricted use, distribution, and reproduction in any medium, provided the original work is properly cited.

\begin{abstract}
Objective. Glucagon-like peptide-1 (GLP-1) analogues (e.g., exenatide) increase insulin secretion in diabetes but less is known about their effects on glucose production or insulin-stimulated glucose uptake in peripheral tissues. Methods. Four groups of SpragueDawley rats were studied: nondiabetic (control, C); nondiabetic + exenatide $(C+E)$; diabetic $(D)$; diabetic + exenatide $(D+E)$ with diabetes induced by streptozotocin and high fat diet. Infusion of $3-{ }^{3} \mathrm{H}$-glucose and $\mathrm{U}-{ }^{13} \mathrm{C}$-glycerol was used to measure basal rates of appearance $\left(\mathrm{R}_{\mathrm{a}}\right)$ of glucose and glycerol and gluconeogenesis from glycerol (GNG). During hyperinsulinemic-euglycemic clamp, glucose uptake into gastrocnemius muscles was measured with 2-deoxy-D- ${ }^{14} \mathrm{C}$-glucose. Results. In the diabetic rats, exenatide reduced the basal $\mathrm{R}_{\mathrm{a}}$ of glucose $(P<0.01)$ and glycerol $(P<0.01)$ and GNG $(P<0.001)$. During the clamp, $\mathrm{R}_{\mathrm{a}}$ of glucose was also reduced, whereas the rate of disappearance of glucose increased and there was increased glucose uptake into muscle $(P<0.01)$ during the clamp. In the nondiabetic rats, exenatide had no effect. Conclusion. In addition to its known effects on insulin secretion, administration of the GLP-1 analogue, exenatide, is associated with increased inhibition of gluconeogenesis and improved glucose uptake into muscle in diabetic rats, implying improved hepatic and peripheral insulin sensitivity.
\end{abstract}

\section{Introduction}

Diabetes is characterized by high blood glucose, which is caused by a variety of mechanisms: increased gluconeogenesis, decreased glucose uptake, and insulin resistance (IR) in liver and skeletal muscle which are the most important factors.

Glucagon-like peptide-1 (GLP-1) is a gut-derived incretin hormone which regulates glucose homeostasis. It has a range of important effects on islet cells, promoting insulin gene transcription and beta-cell proliferation and differentiation. GLP-1 inhibits glucagon secretion through $\alpha$ and $\delta$ cells in the islet $[1,2]$. It also contributes to delay gastric emptying and satiety promotion [3]. However, the potential effect of GLP1 on the regulation of glucose metabolism requires further investigations.

Exenatide is a GLP-1 analogue which is naturally resistant to the proteolytic activity of DPP-IV and has a long-term, highly specific role as a GLP-1 agonist [4] to reduce blood glucose levels in diabetic patients [5]. But, there is a lack of studies concerning the mechanism of effect of GLP-1 analogues on gluconeogenesis (GNG), hepatic glucose production (HGP), or glucose disappearance (Rd) and glucose uptake in gastrocnemius muscle in dynamic and steady-state situations. Furthermore, most of these are limited in vitro studies or clinical observational studies $[6,7]$.

In the current study, we used isotope tracer technology to dynamically explore the effect of GLP-1 analogues on hepatic and extrahepatic glucose homeostasis in diabetic rats.

\section{Materials and Methods}

2.1. Animals. The Sprague-Dawley rats (6 weeks, male, $130 \mathrm{~g}$ ) were established diabetic model according to a published protocol [8]. The diabetic rats were fed a high-fat diet ( $40 \%$ of 
calories from fat) for 10 weeks, followed by a single low-dose intraperitoneal injection of streptozotocin (STZ, $30 \mathrm{mg} / \mathrm{kg}$, Sigma, St. Louis, MO, USA), whose plasma glucose level increased to $16.7 \mathrm{mmol} / \mathrm{L}$ within 3 days after STZ treatment and which remained at this level throughout the study period. The nondiabetic control rats were fed a chow diet $(10.3 \%$ of calories from fat) and received an intraperitoneal injection of citrate-phosphate buffer of the same volume as that given to the diabetic model rats. Nondiabetic rats were assigned either to treatment with vehicle (nondiabetic control, C, $n=6$ ) or with exenatide (nondiabetic + exenatide, $\mathrm{C}+$ $\mathrm{E}, n=6$ ). Diabetic rats were also assigned to one of two treatments: vehicle-treated (diabetic, $\mathrm{D}, n=5$ ) or exenatide treated (diabetic + exenatide, $\mathrm{D}+\mathrm{E}, n=5$ ). All animal procedures conformed to the ethical principles in animal research adopted by the Department of Laboratory Animal Science, Jiaotong University School of Medicine, Shanghai, China.

2.2. Treatment of Exenatide. Intervention with exenatide (Eli Lilly, USA) was initiated on the third day after STZ injection and lasted for 8 weeks. Exenatide was administered by subcutaneous injection at a dose of $5 \mu \mathrm{g} /$ day. The control group rats were given the same volume of normal saline solution every day.

\subsection{Isotope Infusion and Measurement. All rats were fasted} overnight (12-14 hours) and studied the following morning. After local anesthesia with lidocaine, catheters were inserted into the lateral tail vein for infusion of tracers and in the tail artery for blood sampling as described previously [9]. Throughout the experiments, animals were conscious and relaxed; they groomed normally and drank water periodically or sat calmly, indicating that stress resulting from the procedures was minimal (Figure 1). $3{ }^{3} \mathrm{H}$-Glucose (PerkinElmer, Waltham, MA, USA) and U- ${ }^{13} \mathrm{C}$-glycerol (Cambridge Isotope, Andover, MA, USA) were constantly infused through the i.v. infusion line driven by a Harvard mini-infusion pump (Harvard Apparatus, Holliston, MA, USA) for $75 \mathrm{~min}$ (basal period). The infusion rates were $0.5 \mu \mathrm{Ci} / \mathrm{kg} / \mathrm{min}\left(3-{ }^{3} \mathrm{H}-\right.$ glucose) and $0.84 \mu \mathrm{mol} / \mathrm{kg} / \mathrm{min}\left(\mathrm{U}_{-}{ }^{13} \mathrm{C}\right.$-glycerol). Blood was sampledprior to infusion of tracer and at 65,70 , and $75 \mathrm{~min}$. Subsequently, while the $3-{ }^{3} \mathrm{H}$-glucose infusion continued, a primed and continuous infusion of recombinant human insulin ( $5 \mathrm{mIu} / \mathrm{kg} / \mathrm{min}$, Novolin R, Novo Nordisk, Denmark) was initiated for another $90 \mathrm{~min}$ (chase period). The plasma glucose concentration was kept constant at the basal level by monitoring the plasma glucose every 10 minutes and empirically adjusting the infusion rate of a $50 \%$ glucose solution. Twenty minutes before the end of the chase period, $1 \mu \mathrm{Ci}$ of 2-deoxy-D- $-{ }^{14} \mathrm{C}$-glucose (PerkinElmer) was injected through the i.v. infusion line to enable measurement of tissue glucose uptake. During the final 10 minutes, 3 more blood samples were collected at 5-minute intervals. A flow chart of the study design is shown in Figure 2. The rats were euthanized by heart opening under anesthesia with pentobarbital $(50 \mathrm{mg} / \mathrm{kg})$ to reduce the blood content of the tissues. A biopsy was promptly taken from gastrocnemius muscle, cut

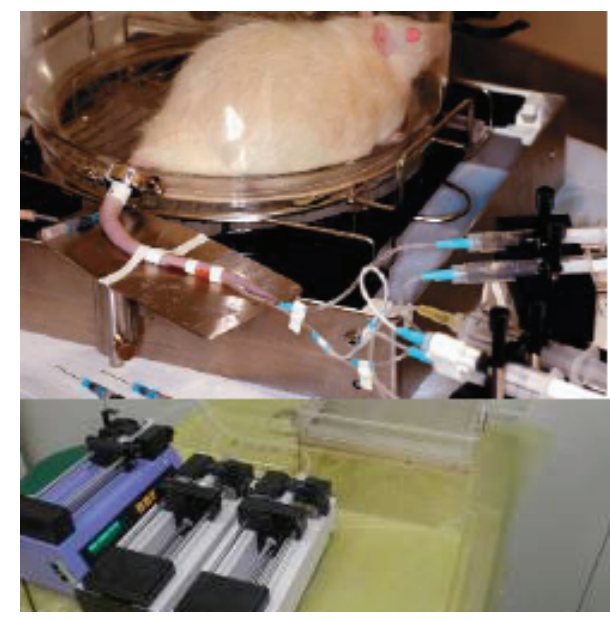

FIGURE 1: Tracer perfusion platform in the rat. Catheters were inserted into the tail artery and vein. This procedure used small incisions and enabled the rats to be kept conscious and relaxed throughout the experiment. It was constantly infused through the i.v. infusion line driven by a Harvard mini-infusion pump (Harvard Apparatus, Holliston, MA, USA) for $75 \mathrm{~min}$ (basal period). The infusion rates were $0.5 \mu \mathrm{Ci} / \mathrm{kg} / \mathrm{min}\left(3-{ }^{3} \mathrm{H}\right.$-glucose $)$ and $0.84 \mu \mathrm{mol} / \mathrm{kg} / \mathrm{min}$ (U- ${ }^{13} \mathrm{C}$-glycerol). Blood was sampled prior to infusion of tracer and at 65,70 , and $75 \mathrm{~min}$. Subsequently, while the $3-{ }^{3} \mathrm{H}$-glucose infusion continued, a primed and continuous infusion of recombinant human insulin $5 \mathrm{mIu} / \mathrm{kg} / \mathrm{min}$ was initiated for another $90 \mathrm{~min}$. The plasma glucose concentration was kept constant at the basal level by monitoring the plasma glucose every 10 minutes and empirically adjusting the infusion rate of a $50 \%$ glucose solution. Twenty minutes before the end of the chase period, $1 \mu \mathrm{Ci}$ of 2-deoxy-D- ${ }^{14} \mathrm{C}$-glucose was injected through the i.v. infusion line to enable measurement of tissue glucose uptake. During the final 10 minutes, 3 more blood samples were collected at 5-minute intervals.

into small pieces and immersed in liquid nitrogen, and stored at $-80^{\circ} \mathrm{C}$. Plasma samples were prepared on ice, centrifuged at $4^{\circ} \mathrm{C}$, separated, and stored at $-80^{\circ} \mathrm{C}$ until assayed.

Glucose concentration was determined by the glucose oxidase method (Beckman Glucose Analyzer, Beckman instruments, Fullerton, CA, USA). Insulin concentration was measured using a magnetic affinity immunoassay (Insulin MPAIA Kit). Plasma lipid concentrations were assayed using a Siemens Dimension MAX integrated chemistry system (Siemens Healthcare Diagnostics Inc.).

An acid digestion method was applied to blood samples and gastrocnemius tissue before determining ${ }^{3} \mathrm{H}$ and ${ }^{14} \mathrm{C}$ radioactivity by liquid scintillation counting (LS6500 Multipurpose Scintillation Counter, Beckman, USA) as previously described [10]. Enrichment of glycerol and glucose was measured by GC-MS analysis of their trimethylsilyl derivatives. Briefly, $1 \mu 1$ of the samples was injected (splitless mode) into a gas chromatograph (Auto System XL GC, PerkinElmer) equipped with a $30 \mathrm{~m}$ fused silica capillary column (DB-5MS, Agilent, USA) and interfaced with a mass spectrometer (TurboMass MS, PerkinElmer) operating in the electronic impact ionization mode. The carrier gas was helium. The operating conditions were as follows: injector at $270^{\circ} \mathrm{C}$ and oven at $70^{\circ} \mathrm{C}$ for $4 \mathrm{~min}$ and then increased to $300^{\circ} \mathrm{C}$ at $10^{\circ} \mathrm{C} / \mathrm{min}$. Ions with 


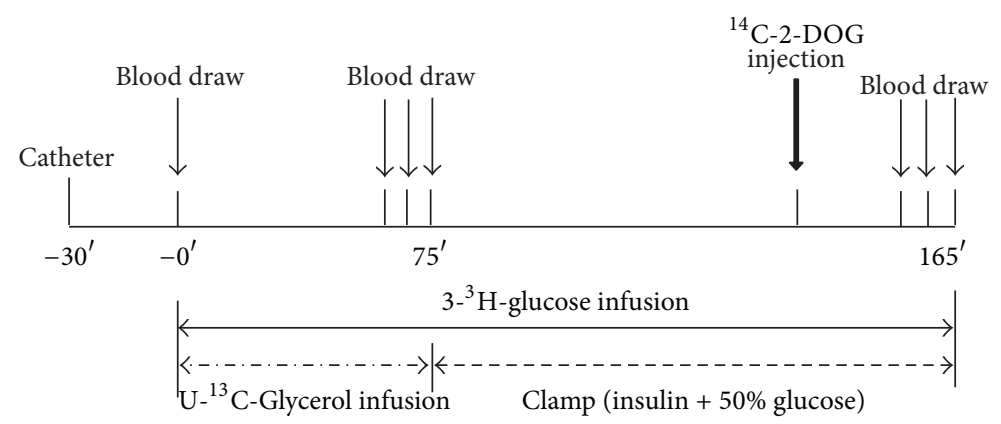

FIGURE 2: Schematic diagram of the tracer infusion protocol. The process of blood collection and tracer infusion from beginning to end.

mass-to-charge ratios $(\mathrm{m} / \mathrm{z})$ of 218 (unlabeled glycerol) and 221 (labeled glycerol) were selectively monitored. The peak area ratio 221/218 was calculated, and the corresponding enrichment (MPE) was determined from standard curves containing weighted amounts of natural and $\mathrm{U}_{-}{ }^{13} \mathrm{C}$-glycerol and injected before and after biological samples. Similarly, ions with mass-to-charge ratios $(\mathrm{m} / z)$ of 319 (unlabeled glucose) and 322 (labeled 1,2,3- ${ }^{13} \mathrm{C}$-glucose) were also selectively monitored. The peak area ratio 322/319 was calculated, and the corresponding enrichment was determined.

2.4. Calculations. Turnover rates $\left(\mathrm{R}_{\mathrm{a}}\right)$ of glucose and glycerol were calculated with the steady-state equation from the respective tracer infusion rates $(F)$ and enrichment (expressed as specific activity (glucose) or MPE (glycerol)). Glucose $\mathrm{R}_{\text {aglu }}$ was calculated from the $3-{ }^{3} \mathrm{H}$-glucose data, while glycerol $\mathrm{R}_{\text {agly }}$ was determined from the $\mathrm{U}_{-}{ }^{13} \mathrm{C}$-glycerol data. The detailed formulae were as follows [11].

Calculation of gastrointestinal glucose absorption is as follows:

$$
\begin{aligned}
& \mathrm{R}_{\text {aglu }}(\mu \mathrm{mol} / \mathrm{kg} / \mathrm{min}) \\
& =\mathrm{HGP} \\
& =\frac{F_{\text {glu }}(\mu \mathrm{ci} / \mathrm{kg} / \mathrm{min})}{\text { plasma } 3-{ }^{3} \mathrm{H} \text {-glucose specific activity }(\mu \mathrm{ci} / \mu \mathrm{mol})} .
\end{aligned}
$$

Calculation of gastrointestinal glycerol absorption is as follows:

$$
\begin{aligned}
& \mathrm{R}_{\mathrm{agly}}(\mu \mathrm{mol} / \mathrm{kg} / \mathrm{min}) \\
& \quad=\frac{F_{\text {gly }}(\mu \mathrm{mol} / \mathrm{kg} / \mathrm{min})}{\text { plasma U- }{ }^{13} \mathrm{C}-\text { glycerol MPE }}-F_{\text {gly }}(\mu \mathrm{mol} / \mathrm{kg} / \mathrm{min}) .
\end{aligned}
$$

The gluconeogenesis (GNG) from glycerol was calculated from the ${ }^{13} \mathrm{C}$ enrichment of glucose and glycerol as follows [12].

Calculation of glycerol gluconeogenesis rates is as follows:

GNG from glycerol $(\mu \mathrm{mol} / \mathrm{kg} / \mathrm{min})$

$$
=\% \times \mathrm{R}_{\mathrm{aglu}}(\mu \mathrm{mol} / \mathrm{kg} / \mathrm{min}) .
$$

Calculation of the percent glycerol converted to glucose is as follows:

\%glycerol converted to glucose

$$
=\frac{\mathrm{R}_{\text {agly }}(\mu \mathrm{mol} / \mathrm{kg} / \mathrm{min}) \times{ }^{13} \mathrm{C} \text {-glucose MPE }}{F_{\text {gly }}(\mu \mathrm{mol} / \mathrm{kg} / \mathrm{min})} .
$$

The MPE of glucose and glycerol was calculated by curve fitting the enrichment with an exponential fit and extrapolating to the plateau of enrichment.

In the basal state, hepatic glucose production (HGP) is equal to the glucose $\mathrm{R}_{\mathrm{a}}$ after an overnight fast. When blood glucose is in a constant state, $\mathrm{R}_{\mathrm{aglu}}=$ disappearance rate of glucose $\left(\mathrm{R}_{\mathrm{dglu}}\right)$, while, during the hyperinsulinemic clamp studies, HGP is equal to the difference between the total glucose $\mathrm{R}_{\text {aglu }}$ determined by tracer analysis and the directly measured glucose infusion rate (GIR) which helps to maintain euglycemia. The average insulin-stimulated glucose uptake rate of gastrocnemius muscle in the steady state was calculated as previously described [13].

Calculation of glucose intake per unit mass of skeletal muscle is as follows:

$$
\begin{aligned}
& \text { glucose uptake }(\mu \mathrm{mol} / \mathrm{g} / \mathrm{min}) \\
& =\frac{\text { muscle }{ }^{14} \mathrm{C}-2-\mathrm{DOG} \text { radioactivity }(\mathrm{dpm} / \mathrm{g} / \mathrm{min})}{\text { plasma }{ }^{14} \mathrm{C}-2-\mathrm{DOG} \mathrm{SA}(\mathrm{dpm} / \mu \mathrm{mol})} .
\end{aligned}
$$

2.5. Statistical Analysis. The statistical package for the social sciences (SPSS version 17.0) was used for data analysis. All results are expressed as mean $\pm \mathrm{SD}$ and values were compared using one-way ANOVA followed by the Student-NewmanKeuls post hoc test for multiple comparisons as appropriate. Differences were defined as significant at $P<0.05$.

\section{Results}

3.1. Body Weight and Fasting Blood Glucose. There were no significant differences in body weight or fasting blood glucose levels between the four group rats before the experiment. However, a significant reduction in body weight was seen in both $\mathrm{D}+\mathrm{E}$ and $\mathrm{C}+\mathrm{E}$ groups (Table 1).

The fasting blood glucose in the $\mathrm{D}+\mathrm{E}$ group decreased compared with the $\mathrm{D}$ group. It also decreased in the $\mathrm{C}+\mathrm{E}$ 
TABLE 1: Characteristics of rats in the four groups at the end of study.

\begin{tabular}{|c|c|c|c|c|}
\hline & $\begin{array}{c}C \\
(n=6)\end{array}$ & $\begin{array}{c}C+E \\
(n=6)\end{array}$ & $\begin{array}{c}\mathrm{D} \\
(n=5)\end{array}$ & $\begin{array}{c}\mathrm{D}+\mathrm{E} \\
(n=5)\end{array}$ \\
\hline Body weight (g) & $531.9 \pm 37.6$ & $474.3 \pm 24.9^{*}$ & $468.2 \pm 29.0^{*}$ & $397.6 \pm 13.7^{* \mathbf{\Delta} \varphi}$ \\
\hline $\mathrm{FBG}(\mathrm{mmol} / \mathrm{L})$ & $5.57 \pm 0.31$ & $4.25 \pm 0.55^{\#}$ & $15.10 \pm 1.73^{* \boldsymbol{\Delta}}$ & $9.48 \pm 1.61^{* \mathbf{} \S}$ \\
\hline FINS $(\mu \mathrm{Iu} / \mathrm{mL})$ & $12.84 \pm 5.26$ & $15.00 \pm 5.55$ & $29.09 \pm 3.61^{* \mathbf{\Delta}}$ & $18.86 \pm 2.48^{\varphi}$ \\
\hline HOMA-IR & $3.19 \pm 1.38$ & $2.79 \pm 0.94$ & $18.40 \pm 3.84^{* \boldsymbol{\Lambda}}$ & $7.54 \pm 1.58^{* \Delta \S}$ \\
\hline ISI & $-4.15 \pm 0.61$ & $-4.09 \pm 0.35$ & $-6.01 \pm 0.21^{* \mathbf{\Delta}}$ & $-5.12 \pm 0.21^{* \Delta \S}$ \\
\hline $\mathrm{TC}(\mathrm{mmol} / \mathrm{L})$ & $1.19 \pm 0.23$ & $1.02 \pm 0.14$ & $1.85 \pm 0.16^{* \Delta}$ & $1.61 \pm 0.11^{* \Delta \varphi}$ \\
\hline $\mathrm{TG}(\mathrm{mmol} / \mathrm{L})$ & $0.12 \pm 0.04$ & $0.19 \pm 0.06$ & $0.63 \pm 0.08^{* \boldsymbol{\Lambda}}$ & $0.44 \pm 0.07^{* \mathbf{}} \S$ \\
\hline $\mathrm{LDL}(\mathrm{mmol} / \mathrm{L})$ & $0.23 \pm 0.04$ & $0.20 \pm 0.05$ & $0.61 \pm 0.11^{* \boldsymbol{\Delta}}$ & $0.43 \pm 0.13^{* \Delta \S}$ \\
\hline
\end{tabular}

C: nondiabetic control; C + E: nondiabetic + exenatide; D: diabetic; D + E, diabetic + exenatide.

FBG: fasting blood glucose; FINS: fasting plasma insulin; ISI: insulin sensitivity index.

Data are presented as mean $\pm \mathrm{SD}$.

${ }^{*} P<0.01,{ }^{\#} P<0.05$ compared with normal rats (C).

$\mathbf{\Delta}_{P}<0.01$ compared with normal rats treated with exenatide $(\mathrm{C}+\mathrm{E})$.

${ }^{\S} P<0.01,{ }^{\varphi} P<0.05$ compared with diabetic rats treated with vehicle (D).

group rats compared with those in the $\mathrm{C}$ group $(P<0.05)$ (Table 1).

\subsection{Fasting Plasma Insulin (FINS) Levels, Homeostasis Model-} Insulin Resistance (HOMA-IR), and Insulin Sensitivity Index (ISI). The FINS concentration in the D + E group (18.86 \pm $2.48 \mu \mathrm{Iu} / \mathrm{mL}$ ) was significantly lower than that in the $\mathrm{D}$ group rats $(29.09 \pm 3.61 \mu \mathrm{Iu} / \mathrm{mL}, P<0.01)$, while no difference was found between $C$ group rats $(12.84 \pm 5.26 \mu \mathrm{Iu} / \mathrm{mL})$ and the $\mathrm{C}$ $+\mathrm{E}$ group rats $(15.00 \pm 5.55 \mu \mathrm{Iu} / \mathrm{mL})$. The HOMA-IR in the $\mathrm{D}+\mathrm{E}$ group rats $(7.54 \pm 1.58)$ was also significantly lower than that in the $\mathrm{D}$ group rats $(18.40 \pm 3.84, P<0.01)$, while it was still significantly higher than that in the $C$ group rats $(3.19 \pm 1.38, P<0.01)$ and the $\mathrm{C}+\mathrm{E}$ group $(2.79 \pm 0.94, P<$ 0.01). Although the HOMA-IR in the $\mathrm{C}+\mathrm{E}$ group rats was lower than that in the $\mathrm{C}$ group rats, this was not significant (Table 1).

The reverse pattern of ISI was observed with the $\mathrm{D}+\mathrm{E}$ group rats having a higher insulin sensitivity index $(-5.12 \pm$ $0.21)$ than the $D$ group rats $(-6.01 \pm 0.21)$, although this was still significantly lower than the $\mathrm{C}$ group rats $(-4.15 \pm 0.61$, $P<0.01)$ and the $\mathrm{C}+\mathrm{E}$ group rats $(-4.09 \pm 0.35, P<0.01)$. The $\mathrm{C}+\mathrm{E}$ group rats had a higher insulin sensitivity index than the $\mathrm{C}$ group rats, but this was not significant (Table 1).

3.3. Plasma Lipid Profile. The $\mathrm{D}+\mathrm{E}$ group rats had lower plasma total cholesterol, triglycerides, and low density lipoprotein-cholesterol level $(1.61 \pm 0.11 \mathrm{mmol} / \mathrm{L}, 0.44 \pm$ $0.07 \mathrm{mmol} / \mathrm{L}$, and $0.43 \pm 0.13 \mathrm{mmol} / \mathrm{L}$, resp.) than the $\mathrm{D}$ group rats $(1.85 \pm 0.16 \mathrm{mmol} / \mathrm{L}, 0.63 \pm 0.08 \mathrm{mmol} / \mathrm{L}$, and $0.61 \pm$ $0.11 \mathrm{mmol} / \mathrm{L}$, resp.); this was still significantly higher than the $\mathrm{C}$ group rats $(1.19 \pm 0.23 \mathrm{mmol} / \mathrm{L}, 0.12 \pm 0.04 \mathrm{mmol} / \mathrm{L}$, and $0.23 \pm 0.04 \mathrm{mmol} / \mathrm{L}$, resp. $)$ and the $\mathrm{C}+\mathrm{E}$ group rats $(1.02 \pm$ $0.14 \mathrm{mmol} / \mathrm{L}, 0.19 \pm 0.06 \mathrm{mmol} / \mathrm{L}$, and $0.20 \pm 0.05 \mathrm{mmol} / \mathrm{L}$, resp.). There was no significant difference in the plasma lipid spectrum between the rats in the $\mathrm{C}$ group and those in the $\mathrm{C}$ + E group (Table 1).
3.4. Basal Rate of Appearance of Glucose. Basal insulin concentrations were as follows: C, $12.84 \pm 5.26 \mu \mathrm{Iu} / \mathrm{mL}$; C + E, $15.00 \pm 5.55 \mu \mathrm{Iu} / \mathrm{mL} ; \mathrm{D}, 29.09 \pm 3.61 \mu \mathrm{Iu} / \mathrm{mL} ;$ and $\mathrm{D}+\mathrm{E}$, $18.86 \pm 2.48 \mu \mathrm{Iu} / \mathrm{mL}$. Corresponding rates of appearance of glucose were as follows: C, $42.27 \pm 10.56 \mu \mathrm{mol} / \mathrm{kg} / \mathrm{min} ; \mathrm{C}+$ E, $35.11 \pm 3.96 \mu \mathrm{mol} / \mathrm{kg} / \mathrm{min}$; D, $121.07 \pm 16.55 \mu \mathrm{mol} / \mathrm{kg} / \mathrm{min}$; and $\mathrm{D}+\mathrm{E}, 94.70 \pm 13.46 \mu \mathrm{mol} / \mathrm{kg} / \mathrm{min}$. The $\mathrm{D}+\mathrm{E}$ group rats had lower glucose appearance rates than the $\mathrm{D}$ group rats $(P<0.01)$, while it had still significantly higher than the $\mathrm{C}$ group rats $(P<0.01)$ and the $\mathrm{C}+\mathrm{E}$ group rats $(P<0.01)$. The $\mathrm{C}+\mathrm{E}$ group rats also had a lower glucose appearance rates than the $C$ group rats, but no significant difference was found (Figure 5(b)).

3.5. Basal Glycerol Appearance and Gluconeogenesis from Glycerol (GNG). The glycerol appearance after an overnight fast was lower $(P<0.01)$ in the $\mathrm{D}+\mathrm{E}$ group rats than that in the $\mathrm{D}$ group rats $(15.75 \pm 2.04$ versus $24.65 \pm$ $5.39 \mu \mathrm{mol} / \mathrm{kg} / \mathrm{min})$. The gluconeogenesis from glycerol was all considerably lower $(P<0.01)$ in the $\mathrm{D}+\mathrm{E}$ group rats than that in the $\mathrm{D}$ group rats [glycerol converted to glucose (\%): $48.23 \pm 11.20 \%$ versus $61.53 \pm 7.44 \%$; gluconeogenesis from glycerol: $9.76 \pm 2.54 \mu \mathrm{mol} / \mathrm{kg} / \mathrm{min}$ versus $17.54 \pm$ $2.68 \mu \mathrm{mol} / \mathrm{kg} / \mathrm{min}$ ] (Figure 3).

3.6. Clamp Concentrations of Blood Glucose and Insulin. After the exogenous insulin infusion $(5 \mathrm{mIu} / \mathrm{kg} / \mathrm{min})$ for 90 minutes, the concentrations of blood glucose at clamp steady state were similar among the four group rats. At the same time, the plasma insulin concentrations of the rats were dramatically elevated compared with their basal state $(P<0.01)$. Specifically, the plasma insulin concentrations of the $C$ group rats increased to $105.95 \pm 7.38 \mu \mathrm{Iu} / \mathrm{mL}$ (the steady state), of the $\mathrm{C}+\mathrm{E}$ group rats increased to $98.60 \pm 6.86 \mu \mathrm{Iu} / \mathrm{mL}$, of the $\mathrm{D}$ group rats increased to $118.92 \pm 8.81 \mu \mathrm{Iu} / \mathrm{mL}$, and of the $\mathrm{D}+\mathrm{E}$ group rats increased to $108.47 \pm 7.91 \mu \mathrm{Iu} / \mathrm{mL}$. Meanwhile, under the clamp steady state, the plasma insulin 


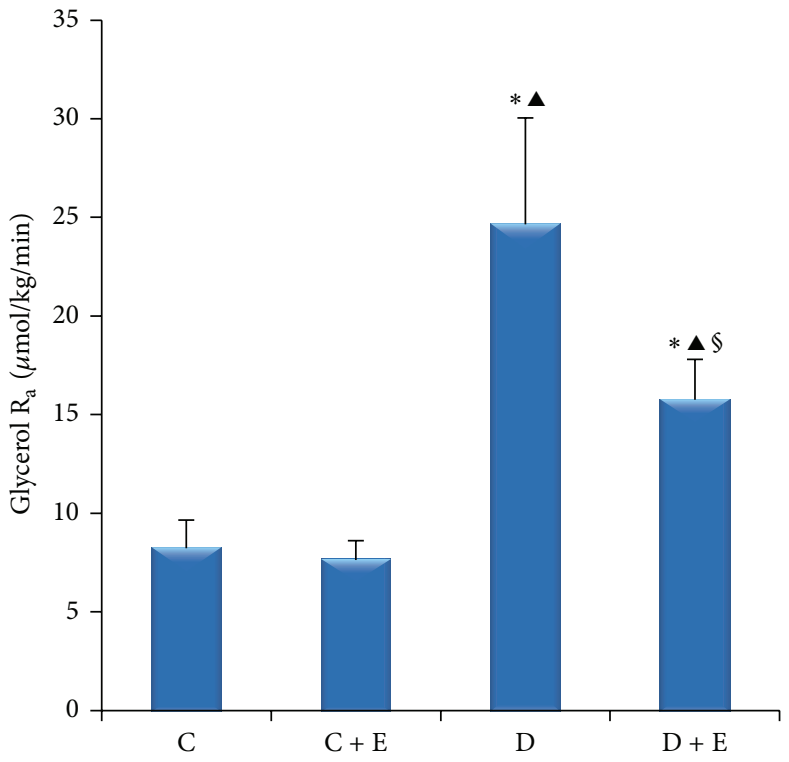

Glycerol $R_{a}$

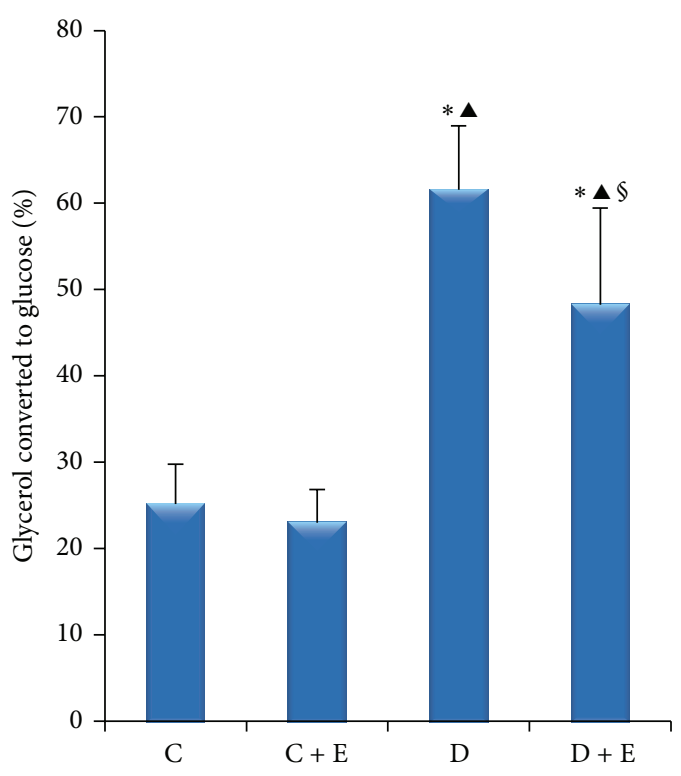

Glycerol converted to glucose (\%)

(b)

(a)

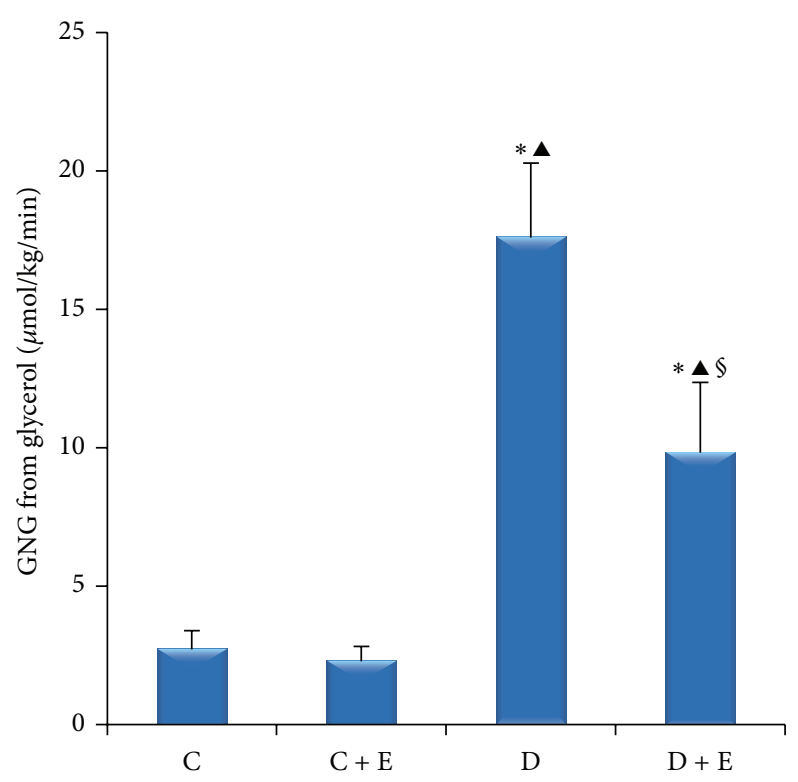

GNG from glycerol $(\mu \mathrm{mol} / \mathrm{kg} / \mathrm{min})$

(c)

FIGURE 3: Plasma parameters of glycerol flux and gluconeogenesis. C: nondiabetic, control; C + E: nondiabetic + exenatide; D: diabetic; D $+\mathrm{E}$ : diabetic + exenatide. $\mathrm{R}_{\mathrm{a}}$ means appearance rate; GNG means gluconeogenesis. Data are presented as mean $\pm \mathrm{SD} .{ }^{*} P<0.01 ;{ }^{*} P<0.05$ compared with C group. ${ }^{\mathbf{\Delta}} P<0.01$ compared with $\mathrm{C}+$ E group. ${ }^{\S} P<0.01$ compared with $\mathrm{D}$ group. Glycerol appearance after an overnight fast was lower $(P<0.01)$ in the $\mathrm{D}+\mathrm{E}$ group rats than that in the $\mathrm{D}$ group rats $(\mathrm{a})$. The gluconeogenesis from glycerol, such as glycerol converted to glucose $(\%)$ and gluconeogenesis from glycerol, was clearly lower $(P<0.01)$ in the $\mathrm{D}+\mathrm{E}$ group rats than that in the $\mathrm{D}$ group rats. (b and c). ${ }^{*} P<0.01,{ }^{\#} P<0.05$ compared with basal. ${ }^{\beta} P<0.01,{ }^{\alpha} P<0.05$ compared with C group. ${ }^{\sigma} P<0.01,{ }^{\gamma} P<0.05$ compared with $\mathrm{C}+$ E group. ${ }^{\S} \mathrm{P}<0.01,{ }^{\varphi} \mathrm{P}<0.05$ compared with $\mathrm{D}$ group. 


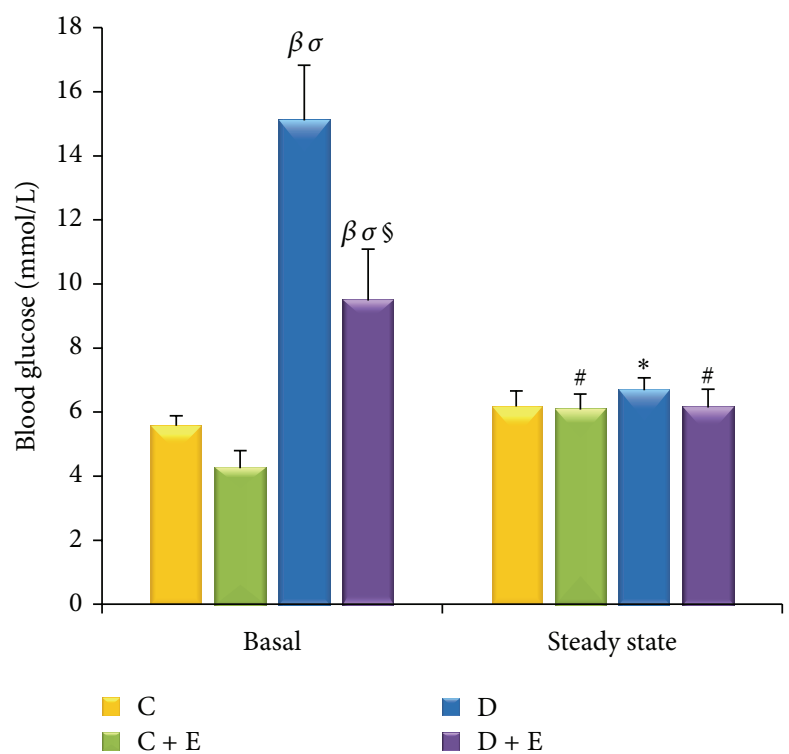

(a)

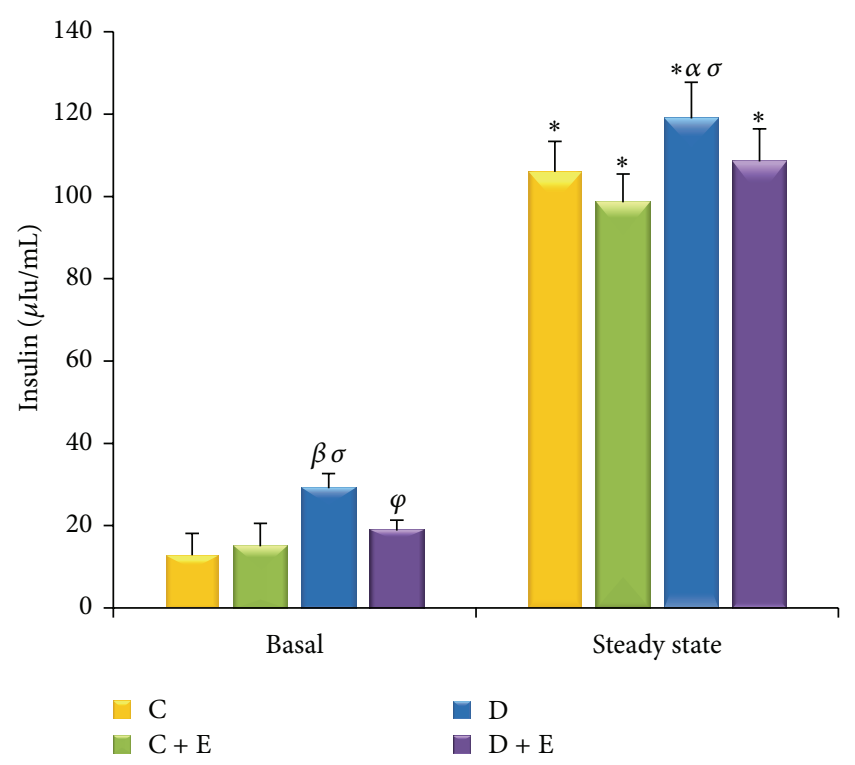

(b)

FIGURE 4: Glucose and insulin concentration during the hyperinsulinemic-euglycemic clamp steady state. The concentrations of blood glucose during the clamp steady state were similar among the four groups of rats. (a) Plasma insulin concentrations of the rats were dramatically elevated compared with their basal state $(P<0.01)$. Furthermore, plasma insulin concentrations in the D group rats were significantly higher than those in the $\mathrm{C}$ group rats $(P<0.05)$ and in the $\mathrm{C}+\mathrm{E}$ group rats $(P<0.01)$ under the clamp steady-state conditions $(\mathrm{b})$. ${ }^{*} P<0.01,{ }^{*} P<0.05$ compared with basal. ${ }^{\beta} P<0.01,{ }^{\alpha} P<0.05$ compared with $\mathrm{C}$ group. ${ }^{\sigma} P<0.01,{ }^{\gamma} P<0.05$ compared with $\mathrm{C}+\mathrm{E}$ group. ${ }^{\S} P<0.01,{ }^{\varphi} P<0.05$ compared with D group.

concentrations in the D group rats were also significantly higher than those in the $\mathrm{C}$ group rats $(P<0.05)$ and those in the $\mathrm{C}+\mathrm{E}$ group rats $(P<0.01)$ (Figures $4(\mathrm{a})$ and $4(\mathrm{~b})$ ).

3.7. Clamp Glucose Infusion Rates. The exogenous glucose infusion rates required to maintain the glucose levels at the clamp point $(6-7 \mathrm{mmol} / \mathrm{L})$ were higher $(P<0.01)$ in the $\mathrm{D}+\mathrm{E}$ group rats than those in the $\mathrm{D}$ group rats $(144.68 \pm$ 11.03 versus $114.50 \pm 9.40 \mu \mathrm{mol} / \mathrm{kg} / \mathrm{min})$, while they were still significantly lower $(P<0.01)$ than those in the $\mathrm{C}$ group rats $(144.68 \pm 11.03$ versus $178.71 \pm 8.73 \mu \mathrm{mol} / \mathrm{kg} / \mathrm{min})$. The glucose infusion rates did not differ between the $\mathrm{C}$ group rats and the $\mathrm{C}+\mathrm{E}$ group rats $(178.71 \pm 8.73$ versus $177.95 \pm$ $9.89 \mu \mathrm{mol} / \mathrm{kg} / \mathrm{min}$ ) (Figure 6(a)).

3.8. Clamp Rate of Appearance of Glucose. Under the euglycaemic, hyperinsulinaemic conditions of the clamp, $\mathrm{R}_{\mathrm{a}}$ of glucose was greater $(P<0.01)$ in the $\mathrm{D}$ group rats than that in the $\mathrm{D}+\mathrm{E}$ group rats $(44.14 \pm 8.49 \mu \mathrm{mol} / \mathrm{kg} / \mathrm{min}$ versus $21.37 \pm 5.89 \mu \mathrm{mol} / \mathrm{kg} / \mathrm{min}$ ) (Figure 5(a)).

3.9. Clamp Glucose Disappearance Rates. After exogenous insulin infusion $(5 \mathrm{mIu} / \mathrm{kg} / \mathrm{min})$ for 90 minutes, the glucose disappearance rates of the $\mathrm{C}$ group rats increased from $42.27 \pm$ 10.56 to $182.16 \pm 9.15 \mu \mathrm{mol} / \mathrm{kg} / \mathrm{min}(P<0.01)$, and increment of $139.9 \mu \mathrm{mol} / \mathrm{kg} / \mathrm{min}$, of the $\mathrm{C}+\mathrm{E}$ group rats increased from $35.11 \pm 3.96$ to $180.87 \pm 8.85 \mu \mathrm{mol} / \mathrm{kg} / \mathrm{min}(P<0.01)$, an increment of $145.76 \mu \mathrm{mol} / \mathrm{kg} / \mathrm{min}$, of the $\mathrm{D}$ group rats increased from $121.07 \pm 16.55$ to $158.63 \pm 6.06 \mu \mathrm{mol} / \mathrm{kg} / \mathrm{min}$ $(P<0.05)$, an increment of $37.56 \mu \mathrm{mol} / \mathrm{kg} / \mathrm{min}$, and of the $\mathrm{D}+\mathrm{E}$ group rats increased from $94.70 \pm 13.46$ to $167.92 \pm 5.50 \mu \mathrm{mol} / \mathrm{kg} / \mathrm{min}(P<0.01)$, an increment of $73.22 \mu \mathrm{mol} / \mathrm{kg} / \mathrm{min}$.

Under the clamp steady state, although the plasma insulin concentrations of the $\mathrm{D}$ group rats were higher than those of the $\mathrm{C}$ group rats $(P<0.05)$ and the $\mathrm{C}+\mathrm{E}$ group rats $(P<$ $0.01)$, their glucose disappearance rates were still lower than those of the $\mathrm{C}$ group rats $(P<0.05)$ and the $\mathrm{C}+\mathrm{E}$ group rats $(P<0.01)$. At the same time, the glucose disappearance rates of the $\mathrm{D}+\mathrm{E}$ group rats were significantly lower than those of the $\mathrm{C}$ group rats $(P<0.01)$ and the $\mathrm{C}+\mathrm{E}$ group rats $(P<0.05)$. Although the glucose disappearance rates of the $\mathrm{D}+\mathrm{E}$ group rats were higher than those of the $\mathrm{D}$ group rats, this was not significant $(P>0.05)$. There was also no significant difference found between the $C$ group rats and the $\mathrm{C}+\mathrm{E}$ group rats $(P>0.05)$ (Figure 5(b)).

3.10. Glucose Uptake in Muscle. Exenatide treatment for 8 weeks markedly increased glucose uptake in diabetic rat gastrocnemius compared with that of vehicle-treated diabetic rats $(0.24 \pm 0.02$ versus $0.17 \pm 0.02 \mu \mathrm{mol} / \mathrm{g} / \mathrm{min}, P<$ 0.01 ). Increased glucose uptake was also found in the $C$ $+\mathrm{E}$ group rats compared with the $\mathrm{C}$ group rats but this was not statistically significant $(0.41 \pm 0.05$ versus $0.37 \pm$ $0.04 \mu \mathrm{mol} / \mathrm{g} / \mathrm{min}$ ) (Figure 6(b)).

\section{Discussion}

Tracer techniques are widely used in research of the metabolism of glucose and of other molecules. Previous 


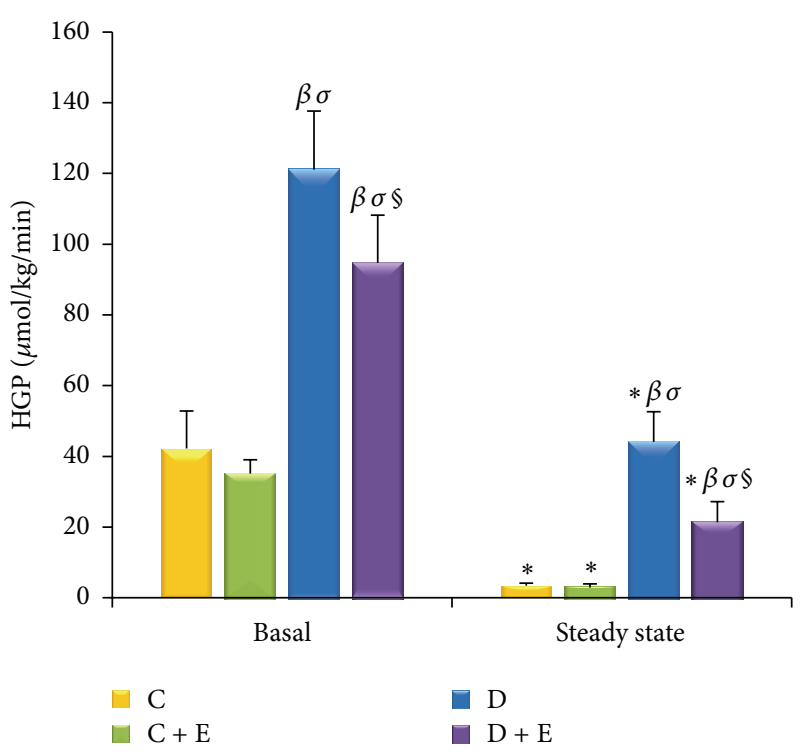

(a)

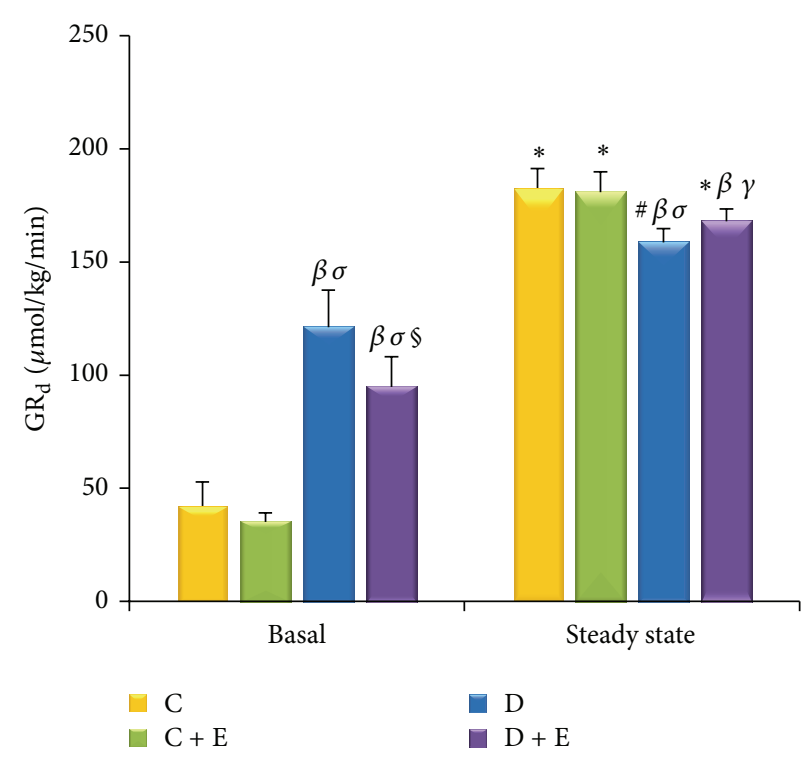

(b)

FIGURE 5: HGP and the disappearance rate of glucose $\left(\mathrm{GR}_{\mathrm{d}}\right)$ during the hyperinsulinemic-euglycemic clamp steady state. HGP following an overnight fast was higher $(P<0.01)$ in the $\mathrm{D}$ group rats than that in the $\mathrm{D}+\mathrm{E}$ group rats. During clamp steady state, HGP was greater $(P<0.01)$ in the $\mathrm{D}$ group rats than that in the $\mathrm{D}+\mathrm{E}$ group rats $(\mathrm{a})$. In the basal state, the $\mathrm{D}+\mathrm{E}$ group rats had a lower $\mathrm{GR}_{\mathrm{d}}$ than the $\mathrm{D}$ group rats $(P<0.01)$. The $\mathrm{C}+\mathrm{E}$ group rats also had a lower $\mathrm{GR}_{\mathrm{d}}$ than the $\mathrm{C}$ group rats, but this was not significantly different $(\mathrm{b})$. Under the clamp steady state, the $\mathrm{GR}_{\mathrm{d}}$ of the $\mathrm{D}$ group rats was lower than that of the $\mathrm{C}$ group rats $(P<0.05)$ and that of the $\mathrm{C}+\mathrm{E}$ group rats $(P<0.01)$. The $\mathrm{GR}_{\mathrm{d}}$ of the $\mathrm{D}+\mathrm{E}$ group rats was also significantly lower than that of the $\mathrm{C}$ group rats $(P<0.01)$ and that of the $\mathrm{C}+\mathrm{E}$ group rats $(P<0.05)$. There was no significant difference found between the $\mathrm{C}$ group rats and the $\mathrm{C}+\mathrm{E}$ group rats $(P>0.05)(\mathrm{b}) .{ }^{*} P<0.01,{ }^{\#} P<0.05$ compared with basal. ${ }^{\beta} P<0.01,{ }^{\alpha} P<0.05$ compared with $\mathrm{C}$ group. ${ }^{\sigma} \mathrm{P}<0.01,{ }^{\gamma} \mathrm{P}<0.05$ compared with $\mathrm{C}+\mathrm{E}$ group. ${ }^{\circledR} \mathrm{P}<0.01,{ }^{\varphi} \mathrm{P}<0.05$ compared with D group.

tracer studies in rat models have often involved invasive surgical placement of catheters in the carotid artery and jugular vein $[14,15]$. Such procedures often require large, deep incisions and extension of catheters through the subcutaneous space-up to the dorsal neck area, which obviously cause stress and may, therefore, require 4-7 days of recovery after surgery. Frequent clotting in these catheters is another problem. All of the above conditions could considerably interfere with the metabolic flux of the substrate and, thus, affect the results.

In the current study, we used a novel approach, in which the catheters were inserted into the rats' tail artery and vein. This procedure required only small incisions and thus rats could be kept conscious and relaxed throughout the experiment. This led to a low level of stress throughout the experiment, thus avoiding disturbance to glucose and lipid metabolism (Figure 1).

Many gastrointestinal hormones, such as GLP-1, orexin, neuropeptide $\mathrm{Y}$, and motilin, play an important role in body's metabolism through regulation of food intake and energy consumption [16]. GLP-1 analogues have a similar effect to other gastrointestinal hormones [17].

In our study, weight loss was observed in both diabetic and nondiabetic rats treated with exenatide, consistent with the appetite reducing effects of GLP-1 analogues and confirming that exenatide affects the body weight of both diabetic and healthy individuals. Fasting blood glucose, insulin, and HOMA-IR were significantly decreased and ISI increased, and there was an accompanying reduction in cholesterol, triglycerides, and low density lipoprotein-cholesterol level.

The results showed glucose and glycerol appearance rates in exenatide-treated diabetic rats were much lower than those in the nontreated diabetic rats. Peripheral adipose tissue degradation is the main source of glycerol during fasting. Because of the lack of glycerokinase in adipose tissue, the glycerol released by lipolysis cannot be resynthesized into adipose tissue, and therefore glycerol appearance rates in the blood are also a reliable indicator for lipolysis [18]. Therefore, it appears that lipolysis in the diabetic rats was partially inhibited by exenatide.

Reductions in basal gluconeogenesis and lipolysis could result from increased insulin secretion, but fasting insulin concentrations were reduced in exenatide-treated rats. The alternative possibility is that exenatide increased sensitivity to insulin. As described above, HOMA-IR was significantly decreased and ISI increased, consistent with improvements in insulin sensitivity and with previous observations of the effects of exenatide on insulin sensitivity $[19,20]$. Previous work on normoglycemic dogs has found improved insulin sensitivity with exenatide, but there appears to be no work on effects of exenatide on insulin sensitivity in a diabetic animal model [21]. There are limitations on the precision of measuring insulin sensitivity through determination of HOMA and ISI but, in the present study, the technique of isotope tracer provides more dynamic data on metabolic flux of carbohydrate with measurement of hepatic glucose 


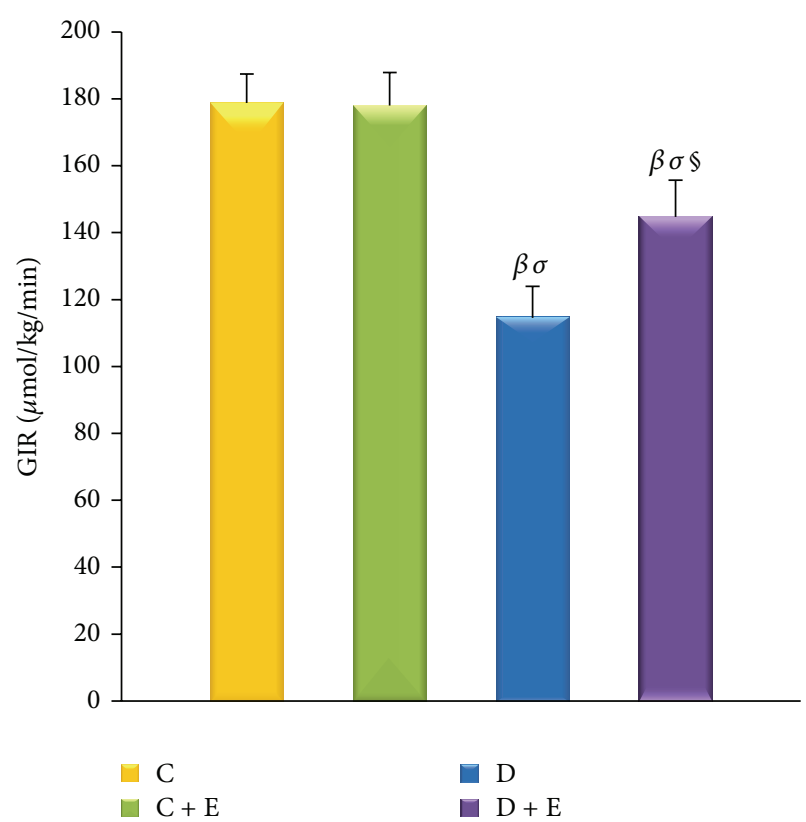

(a)

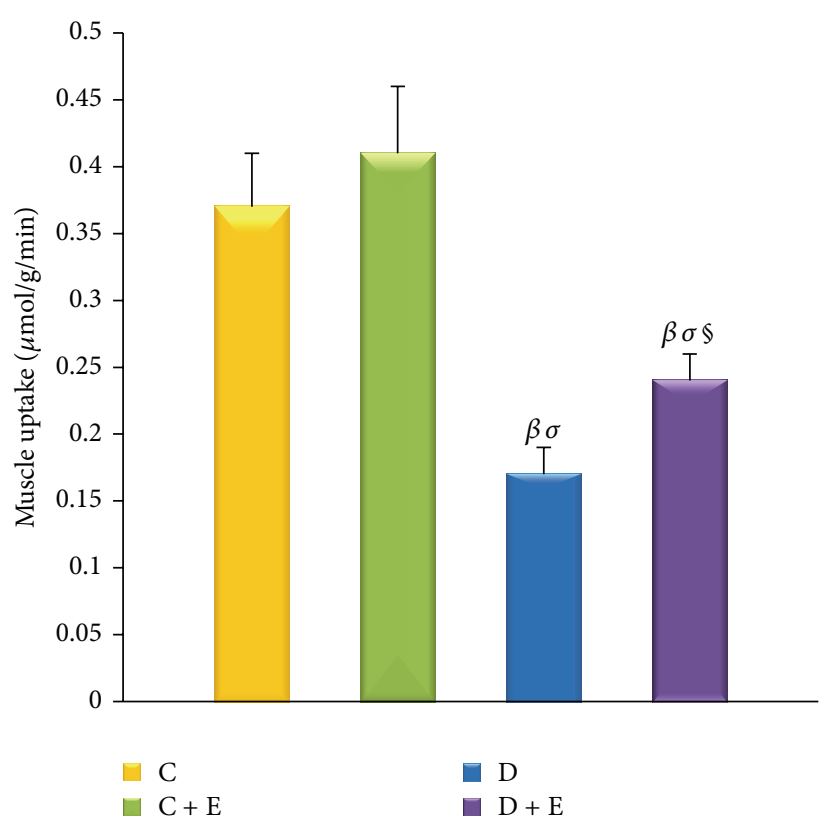

(b)

FIGURE 6: Exogenous glucose infusion rates (GIR) and 2-deoxyglucose uptake into muscle. The GIR required to maintain the glucose levels at the clamp point $(6-7 \mathrm{mmol} / \mathrm{L})$ was higher $(P<0.01)$ in the $\mathrm{D}+\mathrm{E}$ group rats than that in the $\mathrm{D}$ group rats, while it was still significantly lower $(P<0.01)$ than that in the $\mathrm{C}$ group rats. The GIR did not differ between the $\mathrm{C}$ group rats and in the $\mathrm{C}+\mathrm{E}$ group rats (a). Exenatide treatment for 8 weeks markedly increased glucose uptake in diabetic rat gastrocnemius compared with the vehicle-treated diabetic rats $(P<0.01)$. Increased glucose uptake was also found in the $\mathrm{C}+\mathrm{E}$ group rats compared with the $\mathrm{C}$ group rats, but this did not reach statistical significance (b). C: nondiabetic control; C + E: nondiabetic + exenatide; D: diabetic; D + E: diabetic + exenatide. Data are presented as mean \pm SD. ${ }^{*} P<0.01,{ }^{\#} P<0.05$ compared with basal. ${ }^{\beta} P<0.01,{ }^{\alpha} P<0.05$ compared with $\mathrm{C}$ group. ${ }^{\sigma} P<0.01,{ }^{\gamma} P<0.05$ compared with $\mathrm{C}+\mathrm{E}$ group. ${ }^{\S} P<0.01,{ }^{\varphi} P<0.05$ compared with D group.

production and peripheral glucose uptake to directly quantify insulin sensitivity.

Hepatic insulin resistance is frequently seen, even in the prediabetic state [22]. Gluconeogenesis is one of the major sources of fasting endogenous glucose production (EGP), which maintains the body's fasting blood glucose within normal levels $[23,24]$. However, the hepatic insulin resistance seen in diabetes is a major cause of the high level of gluconeogenesis in diabetes.

We used $\mathrm{U}_{-}{ }^{13} \mathrm{C}$-glycerol as a tracer to monitor the naturally occurring kinetics of glycerol metabolism in the different rat groups. $\mathrm{U}_{-}{ }^{13} \mathrm{C}$-Glycerol takes exactly the same chemical structure and function as natural glycerol in the blood, except that three ${ }^{12} \mathrm{C}$ atoms in the carbon chain are replaced by ${ }^{13} \mathrm{C}$. It will follow the same metabolic pathway and not disturb the endogenous glycerol metabolism. Thus, it precisely reflects endogenous glycerol metabolism. These sets of data showed that gluconeogenesis declined significantly (including glycerol converted to glucose (\%) and gluconeogenesis from glycerol) in the exenatide-treated diabetic rats compared with the vehicle-treated diabetic rats. This means that exenatide has the ability to decrease gluconeogenesis in diabetes.

The hyperinsulinemic-euglycemic clamp was used in association with $3-{ }^{3} \mathrm{H}$-glucose infusion. Under hyperinsulinemic conditions, HGP in control rats in the steady-state conditions was almost completely suppressed (more than 90\%) by insulin in contrast to the continuing hepatic glucose production in the diabetic group. Although hepatic insulin resistance was still found in the exenatide-treated diabetic rats, their HGP under the clamp steady-state had been reduced by more than $50 \%$ compared with the vehicle-treated diabetic rats. Thus, these data provide further evidence that exenatide can reduce hepatic insulin resistance in diabetic rats.

During these experiments, the disappearance rates of glucose in the control rats under hyperinsulinemia increased more than 300 percent. In the exenatide-treated diabetic rats a 70 percent increase in glucose disappearance rate was observed, but, in vehicle-treated diabetic rats, there was only a 19 percent increase in glucose disappearance. Accordingly, to maintain the clamp glucose level, the exogenous glucose infusion rates needed to be increased by almost 28 percent in the exenatide compared with the vehicle-treated diabetic rats. These results clearly show that exenatide enhances the effect of insulin on glucose uptake.

Skeletal muscle insulin resistance is the primary defect in diabetes [25], preceding the failure of beta cell function and overt hyperglycemia $[26,27]$. Approximately $80-90 \%$ of exogenous glucose infusion is taken up by skeletal muscle $[28,29]$. 2-Deoxy-glucose has many of the same features as normal glucose; it is able to be taken up by tissues and 
phosphorylated to form 6-P-glucose in the cells. However, no further metabolism occurs, and it is a classic method for measuring glucose uptake ability in target tissues [13]. We used 2-deoxy-D-1- ${ }^{14} \mathrm{C}$-glucose to determine the average glucose uptake rates of skeletal muscle under the clamp steady state.

The glucose uptake rates of gastrocnemius were lowest in the nontreated diabetic rats, with glucose uptake being 46 percent of the uptake rate in the normal control rats. The average glucose uptake rates of gastrocnemius in exenatidetreated diabetic rats were approximately 65 percent of the uptake in the nondiabetic control rats and were 41 percent higher than in the vehicle-treated diabetic rats. This demonstrated that the skeletal muscle insulin resistance was improved by exenatide.

In conclusion, the glucagon-like peptide-1 analog, exenatide, does significantly inhibit hepatic gluconeogenesis and increases glucose uptake in the peripheral muscle tissues to improve hepatic and extrahepatic insulin resistance in diabetic rats.

\section{Conflict of Interests}

No other potential conflict of interests relevant to this paper was reported.

\section{Acknowledgments}

Many thanks are given to Professor Zeng-Kui Guo, Dr. Jensen, Michael, Dr. Andy Basu, and Dr. Rita Basu from Mayo Clinic for their great help in isotope tracer technology. The authors thanks are expressed to Dr. Ian Godsland of Imperial College London for help with the paper. Thanks are due to the project of 973 (2012CB524906) by Ministry of Science and Technology in China, NCFS (81070677), and NSFC (81270885) to support it.

\section{References}

[1] J. Schirra, K. Sturm, P. Leicht, R. Arnold, B. Goke, and M. Katschinski, "Exendin (9-39)amide is an antagonist of glucagon-like peptide-1(7-36)amide in humans," The Journal of Clinical Investigation, vol. 101, no. 7, pp. 1421-1430, 1998.

[2] J. Schirra, M. Nicolaus, R. Roggel et al., "Endogenous glucagonlike peptide 1 controls endocrine pancreatic secretion and antro-pyloro-duodenal motility in humans," Gut, vol. 55, no. 2, pp. 243-251, 2006.

[3] A. M. Deane, N. Q. Nguyen, J. E. Stevens et al., "Endogenous glucagon-like peptide-1 slows gastric emptying in healthy subjects, attenuating postprandial glycemia," Journal of Clinical Endocrinology and Metabolism, vol. 95, no. 1, pp. 215-221, 2010.

[4] E. Wajcberg and A. Tavaria, "Exenatide: clinical aspects of the first incretin-mimetic for the treatment of type 2 diabetes mellitus," Expert Opinion on Pharmacotherapy, vol. 10, no. 1, pp. 135-142, 2009.

[5] D. D. Mafong and R. R. Henry, "Exenatide as a treatment for diabetes and obesity: implications for cardiovascular risk reduction," Current Atherosclerosis Reports, vol.10, no. 1, pp. 5560, 2008.
[6] C. M. Edwards, S. A. Stanley, R. Davis et al., "Exendin-4 reduces fasting and postprandial glucose and decreases energy intake in healthy volunteers," The American Journal of PhysiologyEndocrinology and Metabolism, vol. 281, no. 1, pp. E155-E161, 2001.

[7] L. Arnés, N. González, P. Tornero-Esteban et al., "Characteristics of GLP-1 and exendins action upon glucose transport and metabolism in type 2 diabetic rat skeletal muscle," International Journal of Molecular Medicine, vol. 22, no. 1, pp. 127-132, 2008.

[8] Y. Bi, M. Cai, H. Liang et al., "Increased carnitine palmitoyl transferase 1 expression and decreased sterol regulatory element-binding protein $1 c$ expression are associated with reduced intramuscular triglyceride accumulation after insulin therapy in high-fat-diet and streptozotocin-induced diabetic rats," Metabolism: Clinical and Experimental, vol. 58, no. 6, pp. 779-786, 2009.

[9] Z. Guo and L. Zhou, "Dual tail catheters for infusion and sampling in rats as an efficient platform for metabolic experiments," Lab Animal, vol. 32, no. 2, pp. 45-48, 2003.

[10] D. T. Mahin and R. T. Lofberg, "A simplified method of sample preparation for determination of tritium, carbon-14, or sulfur35 in blood or tissue by liquid scintillation counting," Analytical Biochemistry, vol. 16, no. 3, pp. 500-509, 1966.

[11] A. Vella and R. A. Rizza, "Application of isotopic techniques using constant specific activity or enrichment to the study of carbohydrate metabolism," Diabetes, vol. 58, no. 10, pp. 2168 2174, 2009.

[12] O. Peroni, V. Large, and M. Beylot, "Measuring gluconeogenesis with [2-13C]glycerol and mass isotopomer distribution analysis of glucose," The American Journal of Physiology - Endocrinology and Metabolism, vol. 269, no. 3, pp. E516-E523, 1995.

[13] Z. Guo and L. Zhou, "Muscle type-dependent responses to insulin in intramyocellular triglyceride turnover in obese rats," Obesity Research, vol. 13, no. 12, pp. 2081-2087, 2005.

[14] E. W. Kraegen, D. E. James, S. P. Bennett, and D. J. Chisholm, "In vivo insulin sensitivity in the rat determined by euglycemic clamp," The American Journal of Physiology, vol. 245, no. 1, pp. E1-E7, 1983.

[15] Z. Guo and M. D. Jensen, "Blood glycerol is an important precursor for intramuscular triacylglycerol synthesis," Journal of Biological Chemistry, vol. 274, no. 34, pp. 23702-23706, 1999.

[16] H. Wu, F.-Z. Xia, H. Xu et al., "Acute effects of different glycemic index diets on serum motilin, orexin and neuropeptide $Y$ concentrations in healthy individuals," Neuropeptides, vol. 46, no. 3, pp. 113-118, 2012.

[17] D. P. Bradley, R. Kulstad, and D. A. Schoeller, "Exenatide and weight loss," Nutrition, vol. 26, no. 3, pp. 243-249, 2010.

[18] M. Vaughan, "The production and release of glycerol by adipose tissue incubated in vitro," The Journal of Biological Chemistry, vol. 237, pp. 3354-3358, 1962.

[19] G. Boden, "Obesity, insulin resistance and free fatty acids," Current Opinion in Endocrinology, Diabetes and Obesity, vol. 18, no. 2, pp. 139-143, 2011.

[20] D. C. Klonoff, J. B. Buse, L. L. Nielsen et al., "Exenatide effects on diabetes, obesity, cardiovascular risk factors and hepatic biomarkers in patients with type 2 diabetes treated for at least 3 years," Current Medical Research and Opinion, vol. 24, no. 1, pp. 275-286, 2008.

[21] D. Zheng, V. Ionut, V. Mooradian, D. Stefanovski, and R. N. Bergman, "Exenatide sensitizes insulin-mediated whole-body glucose disposal and promotes uptake of exogenous glucose by the liver," Diabetes, vol. 58, no. 2, pp. 352-359, 2009. 
[22] R. Basu, W. F. Schwenk, and R. A. Rizza, "Both fasting glucose production and disappearance are abnormal in people with "mild" and "severe" type 2 diabetes," American Journal of Physiology: Endocrinology and Metabolism, vol. 287, no. 1, pp. E55-E62, 2004.

[23] B. R. Landau, J. Wahren, V. Chandramouli, W. C. Schumann, K. Ekberg, and S. C. Kalhan, "Contributions of gluconeogenesis to glucose production in the fasted state," The Journal of Clinical Investigation, vol. 98, no. 2, pp. 378-385, 1996.

[24] D. L. Rothman, I. Magnusson, L. D. Katz, R. G. Shulman, and G. I. Shulman, "Quantitation of hepatic glycogenolysis and gluconeogenesis in fasting humans with 13C NMR," Science, vol. 254, no. 5031, pp. 573-576, 1991.

[25] R. A. DeFronzo and D. Tripathy, "Skeletal muscle insulin resistance is the primary defect in type 2 diabetes," Diabetes Care, vol. 32, supplement 2, pp. S157-S163, 2009.

[26] S. Lillioja, D. M. Mott, B. V. Howard et al., "Impaired glucose tolerance as a disorder of insulin action. Longitudinal and crosssectional studies in Pima Indians," The New England Journal of Medicine, vol. 318, no. 19, pp. 1217-1225, 1988.

[27] J. H. Warram, B. C. Martin, A. S. Krolewski, J. S. Soeldner, and C. R. Kahn, "Slow glucose removal rate and hyperinsulinemia precede the development of type II diabetes in the offspring of diabetic parents," Annals of Internal Medicine, vol. 113, no. 12, pp. 909-915, 1990.

[28] E. Ferrannini, D. C. Simonson, L. D. Katz et al., "The disposal of an oral glucose load in patients with non-insulin-dependent diabetes," Metabolism, vol. 37, no. 1, pp. 79-85, 1988.

[29] D. Thiebaud, E. Jacot, R. A. DeFronzo, E. Maeder, E. Jequier, and J. P. Felber, "The effect of graded doses of insulin on total glucose uptake, glucose oxidation, and glucose storage in man," Diabetes, vol. 31, no. 11, pp. 957-963, 1982. 


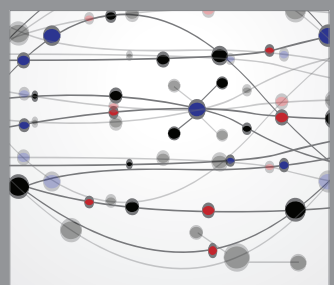

The Scientific World Journal
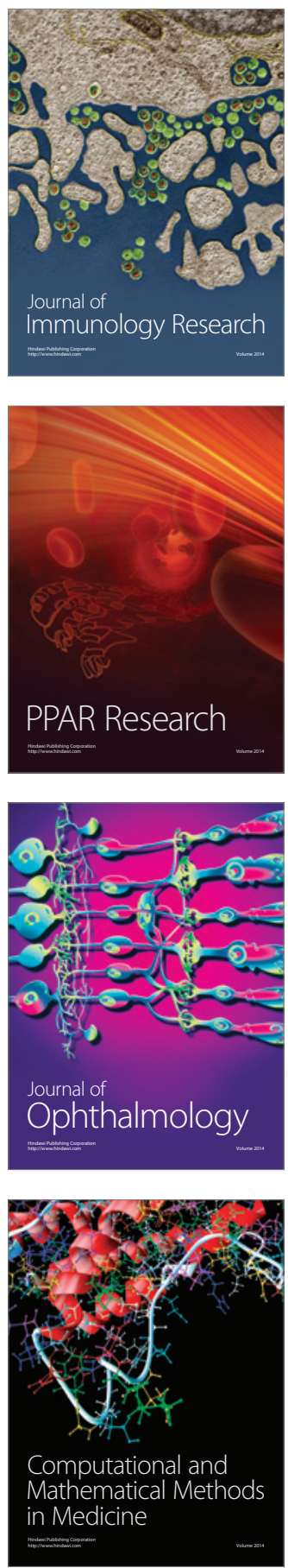

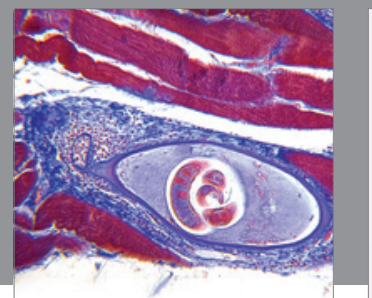

Gastroenterology

Research and Practice
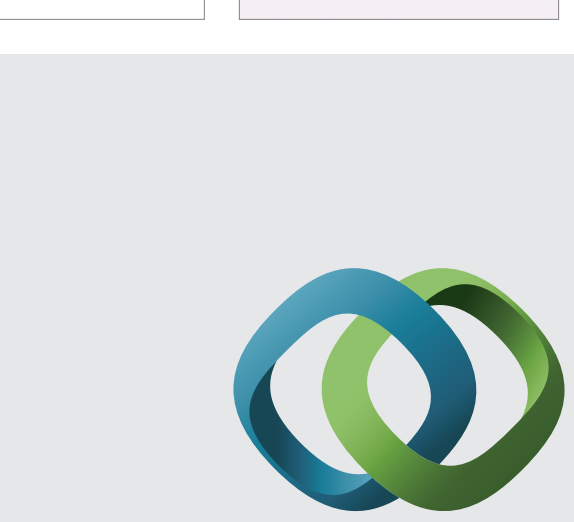

\section{Hindawi}

Submit your manuscripts at

http://www.hindawi.com
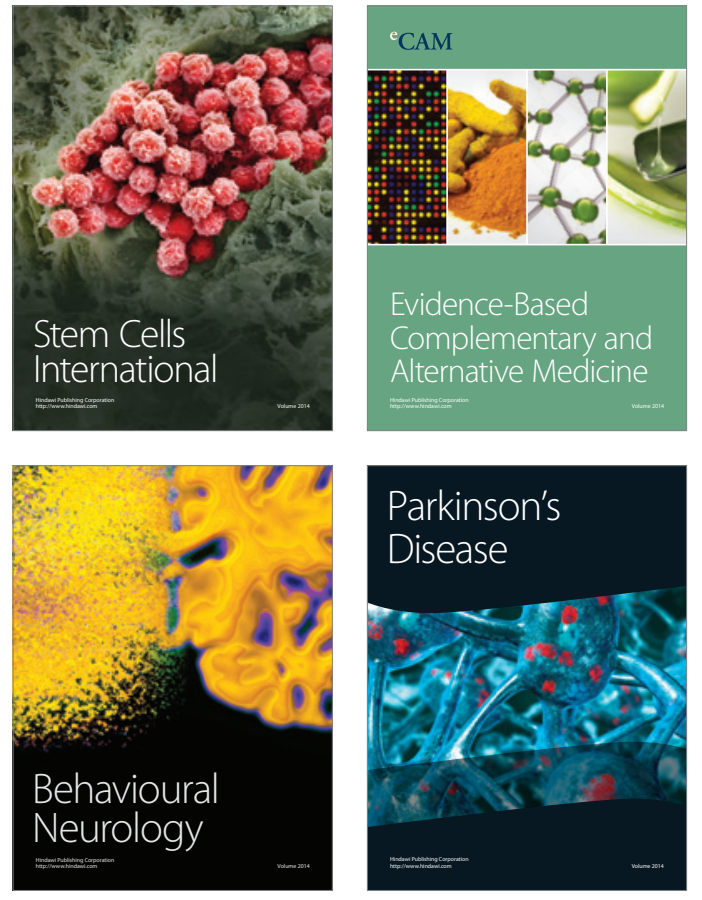
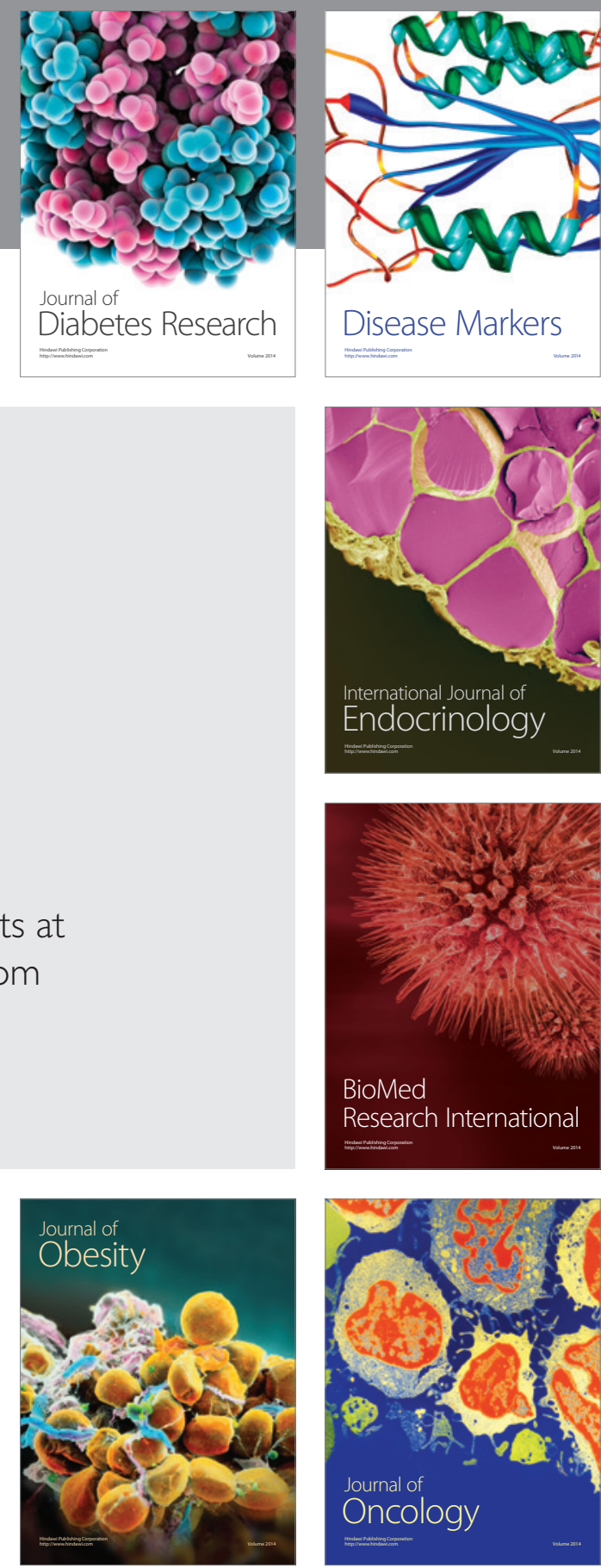

Disease Markers
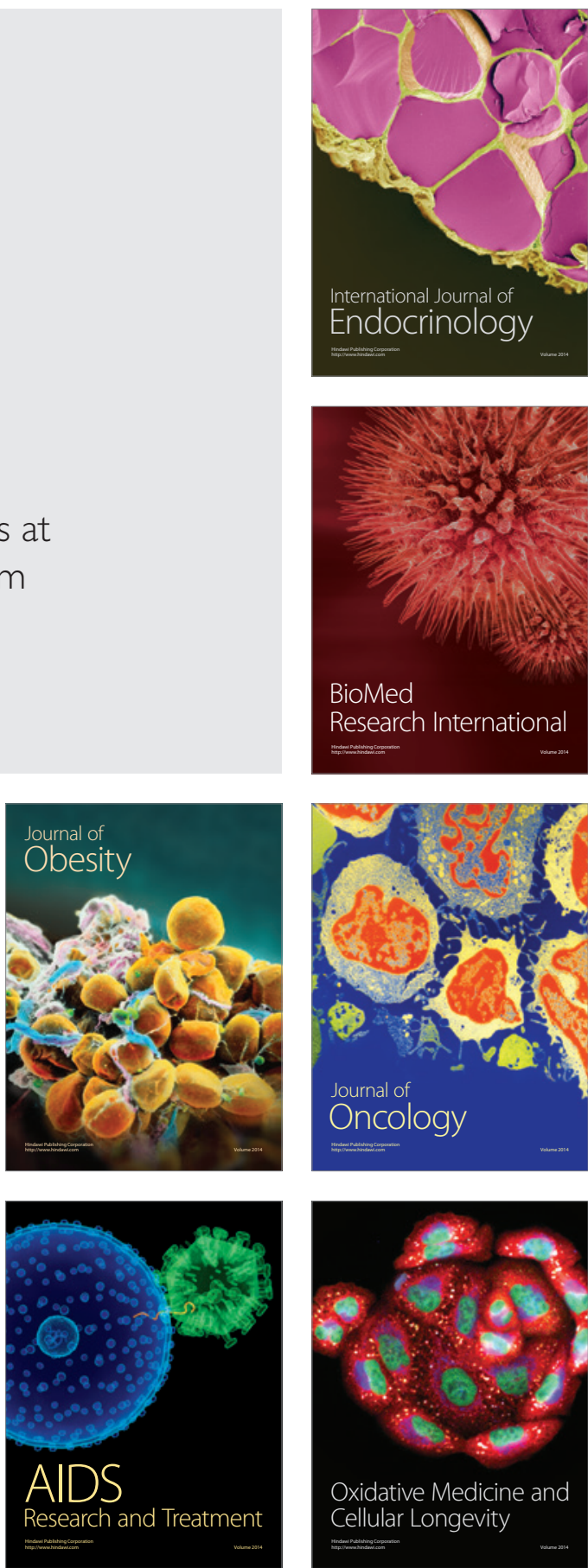